\title{
Efficacy of Tagetes minuta (Asteraceae) essential oil against Rhipicephalus sanguineus (Acari: Ixodidae) on infested dogs and in vitro
}

\author{
Elis Maressa Gonçalves da Silva ${ }^{1}$ Vinicius da Silva Rodrigues ${ }^{2} \cdot$ \\ Jaciara de Oliveira Jorge ${ }^{1}$ - Carolina Fonseca Osava ${ }^{3}$. \\ Matias Pablo Juan Szabó ${ }^{3} \cdot$ Marcos Valério Garcia $^{4}$. \\ Renato Andreotti ${ }^{5}$
}

Received: 13 July 2016/Accepted: 20 October 2016/Published online: 4 November 2016

(C) Springer International Publishing Switzerland 2016

\begin{abstract}
Ticks from Rhipicephalus sanguineus complex are widely distributed in the world and one species from this complex is the most common tick on dogs in Brazil, notably in urban areas. This tick is a vector of several diseases. Among others it transmits the agent of canine Ehrlichiosis, a major dog infectious disease and the agent of Rocky Mountain spotted fever. This tick can spread rapidly and develop intolerable infestations within no time. Currently tick control is done with acaricides and demand for such drugs has grown fast. However, $R$. sanguineus has already developed resistance to the main active compounds and the development of new acaricides is necessary. Many essential oils of plants have acaricidal effect and may be an important source of molecules for the synthesis of new acaricide products. In this study, we evaluated the effectiveness of a new herbal phytotherapic, consisting of the essential oil of Tagetes minuta L., against $R$. sanguineus in vitro and on dogs undergoing experimental infestations. The product displayed $100 \%$ efficacy against larvae, nymphs and adults of the tick on all tested conditions.
\end{abstract}

Keywords Control - Infestations · Phytoterapics - Rhipicephalus sanguineus - Tagetes minuta

Renato Andreotti

renato.andreotti@embrapa.br

1 Faculdade de Medicina Veterinária, Universidade Federal de Uberlândia, Uberlândia, MG, Brazil

2 Laboratório de Biologia do Carrapato, Embrapa Gado de Corte, Universidade Federal de Mato Grosso do Sul, Campo Grande, MS, Brazil

3 Laboratório de Ixodologia, Faculdade de Medicina Veterinária, Universidade Federal de Uberlândia, Uberlândia, MG, Brazil

4 Laboratório de Biologia do Carrapato, Embrapa Gado de Corte/Bolsista DCR Fundect, Governo do Estado de Mato Grosso do Sul, Campo Grande, MS, Brazil

5 Empresa Brasileira de Pesquisa Agropecuária, Embrapa Gado de Corte, Avenida Rádio Maia, 830, Campo Grande, MS CEP 79106-550, Brazil 


\section{Introduction}

Ticks are a major vector of infectious disease agents to both humans and domestic animals (Jongejan and Uilenberg 2004; Estrada-Peña and Jongejan 1999). Among ticks, the Rhipicephalus sanguineus complex has the broadest distribution in the world (Walker et al. 2000; Nava et al. 2015). This complex transmit major dog disease agents such as those of canine ehrlichiosis and babesiosis, (Walker et al. 2000; Guglielmone et al. 2006) and several possibly lethal human pathogens such as, Rickettsia conorii (Estrada-Peña and Jongejan 1999) and Rickettsia rickettsii (Demma et al. 2005).

In Brazil a yet undefined species of the $R$. sanguineus complex is the main dog tick, especially in urban areas (Labruna and Pereira 2001; Szabó et al. 2001, 2010). Dogs are an adequate host for all parasitic stages (Labruna 2004), and dogs do not develop an efficient immune response against the tick (Szabó et al. 1995).

Thus, the wide distribution of $R$. sanguineus within the country, its capacity to attain high infestation levels of both dogs and in household environments and the frequent tickborne diseases of dogs prompt an ever increasing need for tick control. Currently such control relies almost exclusively on chemical acaricides, but resistance of $R$. sanguineus ticks to these chemicals has been reported (Guglielmone et al. 2004). For these reasons new tick control products are in demand.

Phytotherapy is treatment based on the use of plants and herbs. Tagetes minuta L. (Asteraceae), known in Brazil as cravo-de-defunto, is an aromatic plant from South America (Lovatto et al. 2013). The essential oil of this plant has already been shown to control in vitro this and other tick species (Garcia et al. 2012). We herein evaluated the efficacy of a phytotherapic compound from T. minuta, essential oil against $R$. sanguineus both in vitro and on dogs undergoing experimental infestations.

\section{Materials and methods}

\section{Ticks}

Ticks from a laboratory $R$. sanguineus (tropical lineage) colony were used throughout the experiments. Ticks from the colony were fed on tick-bite naive New Zealand rabbits; however, the colony was periodically renewed with engorged females that fed on healthy dogs from Uberlândia, Minas Gerais, Brazil.

\section{Hosts}

For the evaluation of the efficacy of the T. minuta essential oil acaricide on ticks in parasitic phase, male and female mixed-breed dogs were used as hosts. Dog puppies were obtained from private owners, vaccinated and dewormed according to routine veterinary procedures and held for at least one week in a kennel at Federal University of Uberlândia, prior to experimental infestations. Dogs were fed with commercial ration twice per day and water ad libitum. All procedures with animals were approved by the Institutional Committee for Animal Experimentation of the University (protocol 009/13 final document 031/13). 


\section{Phytotherapic acaricide}

A $20 \%$ solution of T. minuta oil in $2 \%$ Tween was used an acaricide, as described previously (Garcia et al. 2012).

\section{Efficacy evaluation against ticks feeding on dogs}

Ticks were placed inside a feeding chamber consisting of a plastic tube with $5 \mathrm{~cm}$ diameter and $3 \mathrm{~cm}$ height, glued, on the previous day, to the shaved back of the hosts as described elsewhere (Szabó et al. 1995). Two feeding chambers at least $15 \mathrm{~cm}$ apart were glued to each animal; the cranial one for acaricide testing and the caudal as control (2\% Tween). Test with each instar was replicated on five animals and a sixth dog infested similarly but with non-sprayed feeding chambers (acaricide or control solution) used as a control for tween solution. Infestations of each feeding chamber consisted of either 25 adult couples, 40 nymphs or 250 tick larvae. $24 \mathrm{~h}$ after tick infestation, each chamber was opened and the interior thereof was sprayed once with $20 \mu \mathrm{L}$ of either control solution or acaricide, after spraying the chambers were closed again.

Chambers were thereafter inspected daily between 08:00 and 09:00 a.m. and either dead or engorged ticks collected. Engorged ticks were counted, weighed (adults individually and immatures in daily batches) and kept at $27{ }^{\circ} \mathrm{C}$ and $80 \%$ humidity for the evaluation of biological parameters.

\section{In vitro efficacy on unfed ticks}

Efficacy of acaricide upon unfed ticks by the immersion test as described by Drummond et al. (1971). Briefly, tick groups of 250 larvae, 40 nymphs or 25 adult couples were immersed in acaricide solution (T. minuta 20\%) in Petri dishes for $5 \mathrm{~min}$ and then dried in filter paper, the ticks were kept at $27{ }^{\circ} \mathrm{C}$ and $80 \%$ humidity for evaluation. Control groups with similar numbers of ticks were immersed in $2 \%$ Tween solution without the acaricide. Evaluations with each tick stage were performed in triplicate included one control group.

The formula used for calculating the efficacy in both tests was according to Aguirre et al. (2015).

\section{Results}

All larvae, nymphs and adults from acaricide sprayed feeding chambers died within $24 \mathrm{~h}$ without engorging whereas most ticks from control feeding chambers in either test or control animals engorged, oviposited or underwent molting to the next stage. Biological parameters of these ticks are presented in Tables 1 and 2. Lack of activity against ticks in control chambers indicates that this phytotherapic acts by contact and does not have systemic effect.

In vitro efficacy on unfed ticks: All unfed larva, nymphs and adults died within $24 \mathrm{~h}$ after immersion in the phytotherapic whereas mortality of control larvae, nymphs and adults within $24 \mathrm{~h}$ was of 5,5 and $8 \%$, respectively. 
Table 1 Biological parameters (mean \pm SD) of Rhipicephalus sanguineus larvae and nymphs fed on dogs inside feeding chambers sprayed with a $20 \%$ solution of Tagetes minuta oil diluted in $2 \%$ Tween (test dog, test feeding chamber) or feeding chambers on the same animal sprayed with a $2 \%$ Tween solution (test dog, control feeding chamber) or in feeding chambers on non-sprayed dog (control dog)

\begin{tabular}{llllllll}
\hline Host & Chamber & Stage & Yield $(\%)$ & Weight $(\mathrm{mg})$ & Feed (days) & Molt (days) & Molt (\%) \\
\hline \multirow{2}{*}{ Test } & Test & Larva & 0 & - & - & - & - \\
& Control & Larva & $53.1 \pm 46.0$ & $0.30 \pm 0.1$ & $5.9 \pm 1.3$ & $7.2 \pm 1.5$ & $85.9 \pm 23.3$ \\
\multirow{2}{*}{ Control } & - & Larva & 92 & $0.33 \pm 0.4$ & $5.11 \pm 0.9$ & $5.4 \pm 0.5$ & 97 \\
Test & Test & Nymph & 0 & - & - & - & - \\
& Control & Nymph & $70.3 \pm 15.2$ & $3.5 \pm 0.3$ & $5.7 \pm 0.9$ & $10.2 \pm 2.2$ & $53.7 \pm 26.2$ \\
\multirow{2}{*}{ Control } & - & Nymph & 67.5 & $3.7 \pm 0.1$ & $5.6 \pm 0.6$ & $8.4 \pm 0.6$ & 63 \\
\hline
\end{tabular}

Table 2 Biological parameters (mean $\pm \mathrm{SD}$ ) of Rhipicephalus sanguineus females fed on dogs inside feeding chambers sprayed with a $20 \%$ solution of Tagetes minuta oil diluted in $2 \%$ Tween (test dog, test feeding chamber) or feeding chambers on the same animal sprayed with a $2 \%$ Tween solution (test dog, control feeding chamber) or in feeding chambers on non-sprayed dog (control dog)

\begin{tabular}{llcc}
\hline $\begin{array}{l}\text { Host } \\
\text { Feeding chamber }\end{array}$ & $\begin{array}{l}\text { Test } \\
\text { Test }\end{array}$ & $\begin{array}{l}\text { Test } \\
\text { Control }\end{array}$ & $\begin{array}{l}\text { Control } \\
\text { Engorged weight (mg) }\end{array}$ \\
\hline Feeding period (days) & - & $116.9 \pm 23.4$ & $115.6 \pm 28.2$ \\
Egg mass weight (mg) & - & $8.4 \pm 0.95$ & $8.3 \pm 0.8$ \\
Pre-oviposition (days) & - & $58.3 \pm 12.6$ & $69.4 \pm 24.3$ \\
Yield (\%) & - & $3.3 \pm 0.6$ & $2.66 \pm 0.9$ \\
IECO (\%) & 0 & $41.7 \pm 23.9$ & 80 \\
Egg hatching $(\%)$ & - & $47.4 \pm 6.1$ & $56.6 \pm 16.1$ \\
\hline
\end{tabular}

\section{Discussion}

The essential oil of T. minuta at a $20 \%$ concentration was lethal to all three $R$. sanguineus stages. Those experiments in vitro proved the efficacy of the phytotherapic upon unfed ticks. Such an effect is important for routine control against unfed ticks on the host prior to attachment as well as in the off-host environment. The same lethality was observed during experimental infestations on ticks that were already attached to dogs and the overall efficacy was $100 \%$ under the experimental conditions. Thus, this product would be acceptable by the Agricultural Ministry of Brazil which demands an efficacy above $95 \%$ for acaricides.

The observed results were not surprising because the $T$. minuta essential oil tested against other tick species in Brazil displayed a similar efficacy. Garcia et al. (2012) tested in vitro the same concentration of the oil against Rhipicephalus microplus, $R$. sanguineus, Amblyomma sculptum and Argas miniatus, and in all cases, the efficacy was above $95 \%$. Andreotti et al. (2013) tested the product as an oil with a concentration of $20 \%$ in vivo against ticks on bovines kept in stalls. The cattle were experimentally infested with $R$. 
microplus larvae on days 0,9 and 18 and treated on day 20 to evaluate effect upon all tick stages. These authors obtained an overall efficacy of $99.98 \%$ for the oil against $R$. microplus under such experimental conditions.

Several recent works evaluated the in vitro efficacy of plant extracts against $R$. microplus, but only a few evaluated the efficacy against $R$. sanguineus. Additionally, a broad array of experimental conditions was used, but only a few reported high tick lethality with low extract concentrations. Olivo et al. (2008) evaluated citronella [Cymbopogon nardus (L.) Rendle] oil at concentrations of 1, 10 or $25 \%$ and observed an efficacies of, $92.1,85.6$ and $87.8 \%$ respectively. Sousa et al. (2008) observed that the extract of unripe Melia azedarach fruit induced a $100 \%$ mortality of $R$. microplus ticks at a concentration of $0.25 \%$. Ribeiro et al. (2008) evaluated the efficacy of Calea serrata extracts against $R$. microplus and $R$. sanguineus larvae as well as $R$. microplus engorged females using four organic hexane extract concentrations $(50,25,12.5$, and $6.25 \mathrm{mg} / \mathrm{ml})$, and observed an overall efficacy of $100 \%$. Broglio-Micheletti et al. (2009) evaluated alcoholic extracts of four plant species (Annona muricata, Syzygium malaccensis, Cymbopogon citratus, Azadirachta indica) at a concentration of $2 \%$ and the hexane extract of $A$. indica at a concentration of $2 \%$ against $R$. microplus. Among these, only the A. muricata extract displayed a $100 \%$ efficacy against engorged females. Broglio-Micheletti et al. (2010) observed an efficacy of $96 \%$ against engorged females of $R$. microplus using an A. indica seed extract and emulsifiable oil at a concentration of $2 \%$ (weight/volume). Terassani et al. (2012) used an $A$. indica extract against $R$. microplus and observed a decrease in egg hatching and an increase in female tick mortality of $30 \%$, but this extract had an overall efficacy of only 14\%. Santos and Vogel (2012) used very high concentrations (50 and $100 \%$ ) of basil (Ocimum basilicum L.) essential oil and obtained $100 \%$ efficacy against fully engorged $R$. microplus females. However, at a lower concentration (25\%), the efficacy decrease to $50 \%$. Santos et al. (2013) evaluated the extracts of 21 plant species against $R$. microplus larvae and observed that 18 had efficacies greater than $95 \%$. The same authors reported an efficacy of $88 \%$ against engorged females of the same tick species with an extract of Angelonia hirta at a concentration of $40 \%$.

Vegetable products are biodegradable and may provide acaricide products that are safer and less harmful towards the environment and humans (Roel 2001; Viegas Junior 2003; Campos et al. 2012). In fact, plant essential oils have long been used for many years for pest control, and they display excellent efficacy in in vitro studies. However, in Brazil, only a few studies were conduction the efficacy of plant essential oil against ticks on animals, and most of those studies involved R. microplus, because of its importance in the cattle industry (Andreotti and Koller 2013). Borges et al. (2011) estimated that extract of 55,000 plant species from 26 families have already been tested against this tick species. It is possible that many of the extracts that were efficacious against $R$. microplus have similar efficacies against $R$. sanguineus, as the case in the present study.

In addition to the toxicity of a plant against arthropods, other aspects should be evaluated to create a commercial product. Such a product should have efficacy against pests at low concentrations, should not be toxic to mammals, its harvesting, manipulation and application should be easy and commercially feasible (Viegas Junior 2003). Furthermore, because the acaricide compounds of plants may vary according to the plant species, cultivation and extraction forms, its chemical constitution should be determined to enable control upon such variations (Knaak and Fiuza 2010). In conclusion, the essential oil of $T$. minuta at $20 \%$ in Tween at $2 \%$ displayed a high acaricidal effect. But further studies are needed to be able to say that the essential oil of T. minuta is an alternative to control $R$. sanguineus tick. 
Acknowledgements The research was supported by Coordenação de Aperfeiçoamento de Pessoal de Nível Superior-CAPES, Conselho Nacional de Desenvolvimento Científico e Tecnológico-CNPq, Fundação de Apoio ao Desenvolvimento do Ensino, Ciência e Tecnologia do Estado de Mato Grosso do Sul-FUNDECTMS, Mato Grosso do Sul State and Fundação de Amparo a Pesquisa do Estado de Minas Gerais-FAPEMIGMG.

\section{Compliance with ethical standards}

Conflict of interest Authors declare no conflict of interest.

Ethical approval All procedures performed in studies involving animals were in accordance with the ethical standards of the institution or practice at which the studies were conducted (Animal Experimentation Ethics Committee of the Federal University of Uberlândia). Permits and Approvals (protocol 009/13 final document 031/13) are on file in the office of M.P.J.S.

\section{References}

Aguirre ARA, Garcia MV, Szabo MPJ, Barros JC, Andreotti R (2015) Formula to evaluate efficacy of vaccines and systemic substances against three-host ticks. Int J Parasitol 45:357-359. doi:10.1016/j. ijpara.2015.02.003

Andreotti R, Koller WW (2013) Carrapatos no Brasil: Biologia, Controle e Doenças Transmitidas. Embrapa, Brasília

Andreotti R, Garcia MV, Cunha RC, Barros JC (2013) Protective action of Tagetes minuta (Asteraceae) essential oil in the control of Rhipicephalus microplus (Canestrini, 1887) (Acari: Ixodidae) in a cattle pen trial. Vet Parasitol 197:341-345. doi:10.1016/j.vetpar.2013.04.045

Borges LMF, Sousa LAD, Barbosa CS (2011) Perspectivas para o uso de extratos de plantas para o controle do carrapato de bovinos Rhipicephalus (Boophilus) microplus. Rev Bras Parasitol Vet 20:89-96

Broglio-Micheletti SMF, Valente ECN, Souza LA, Dias NS, Araújo AMN (2009) Extratos de plantas no controle de Rhipicephalus (Boophilus) microplus (Canestrini, 1887) (Acari: Ixodidae) em laboratório. Rev Bras Parasitol Vet 18:44-48. doi:10.4322/rbpv.01804008

Broglio-Micheletti SMF, Dias Nda S, Valente ECN, de Souza LA, Lopes DOP, Dos Santos JM (2010) Action of extract and oil neem in the control of Rhipicephalus (Boophilus) microplus (Canestrini, 1887) (Acari: Ixodidae) in laboratory. Rev Bras Parasitol Vet 19:46-50. doi:10.4322/rbpv.01901008

Campos RNS, Bacci L, Araujo APA, Blank AF, Arrigoni-Blank MF, Santos GRA, Roner MNB (2012) Óleos essenciais de plantas medicinais e aromáticas no controle do carrapato Rhipicephalus microplus. Archiv Zootec 61:67-78

Demma LJ, Traeger MS, Nicholson WL, Paddock CD, Blau DM, Eremeeva ME, Dasch GA, Levin ML, Singleton J, Zaki SR, Cheek JE, Swerdlow DL, Mcquiston JH (2005) Rocky Mountain spotted fever from an unexpected tick vector in Arizona. New Engl J Med 353:587-594

Drummond RO, Gladney WJ, Whetstone TM, Ernst SE (1971) Testing of insecticides against the tropical horse tick in the laboratory. J Econ Entomol 64:1164-1166

Estrada-Peña A, Jongejan F (1999) Ticks feeding on humans: a review of records on human-biting Ixodoidea with special reference to pathogen transmission. Exp App Acarol 23:685-715

Garcia MV, Matias J, Barros JC, Lima DP, Lopes RS, Andreotti R (2012) Chemical identification of Tagetes minuta Linnaeus (Asteraceae) essential oil and its acaricidal effect on ticks. Rev Bras Parasitol Vet 21:405-411. doi:10.1590/S1984-29612012000400011

Guglielmone AA, Bechara GH, Szabó MPJ, Barros-Battesti DM, Faccini JLH, Labruna MB, De La Vega R, Arzua M, Campos Pereira M, Furlong J, Mangold AJ, Martins JR, Rodríguez M, Serra-Freire NM, Venzal JM (2004) Ticks of importance for domestic animals in Latin America and Caribbean countries. Printed on CD by the International Consortium on Ticks and Tick-borne Diseases- 2 of the European Comission INCO-DEV programme

Guglielmone AA, Szabó MPJ, Martins JRS, Estrada-Peña A (2006) A Diversidade e importância de carrapatos na sanidade animal. In: Barros-Battesti DMB, Arzua M, Bechara GH (eds) Carrapatos de importância medico-veterinária da região neotropical: um guia ilustrado para identificação de espécies. Vox/ICTTD-3/Butantan, São Paulo, pp 115-138

Jongejan F, Uilenberg G (2004) The global importance of ticks. Parasitology 129:3-14. doi:10.1017/ S0031182004005967

Knaak N, Fiuza LM (2010) Potencial dos óleos essências de plantas no controle de insetos e microrganismos. Neotrop Biol Conserv 5:120-132. doi:10.4013/nbc.2010.52.08 
Labruna MB (2004) Biologia-ecologia de Rhipicephalus sanguineus (Acari: Ixodidae). Rev Bras Parasitol Vet 13:123-124

Labruna MB, Pereira MC (2001) Carrapato em cães no Brasil. Clín Vet 30:24-32

Lovatto PB, Schiedeck G, Mauch CR (2013) Extratos aquosos de Tagetes minuta (Asteraceae) como alternativas ao manejo agro-ecológico de afídeos em hortaliças. Interciência 38:676-680

Nava S, Estrada-Penã A, Petney T, Beati L, Labruna MB, Szabó MPJ, Venzal VM, Mastropaolo M, Mangolda AJ, Guglielmone AA (2015) The taxonomic status of Rhipicephalus sanguineus (Latreille, 1806). Vet Parasitol 208:2-8. doi:10.1016/j.vetpar.2014.12.021

Olivo CJ, Carvalho NM, Silva JHS, Vogel FF, Massariol P, Meinerz G, Agnolin C, Morel AF, Viau LV (2008) Óleo de citronela no controle do carrapato de bovinos. Cienc Rural 38(2):406-410

Ribeiro VLS, Avancini C, Gonçalves K, Toigo E, Poser G (2008) Acaricidal activity of Calea serrata (Asteraceae) on Boophilus microplus and Rhipicephalus sanguineus. Vet Parasitol 151:351-354. doi:10.1016/j.vetpar.2007.11.007

Roel AR (2001) Utilização de plantas com propriedades inseticidas: uma contribuição para o Desenvolvimento Rural Sustentável. Rev Int Desenvolv Local 1:43-50

Santos FCC, Vogel FSF (2012) Avaliação in vitro da ação do óleo essencial de capim limão (Cymbopogon citratus) sobre o carrapato bovino Rhipicephalus (Boophilus) microplus. Rev Bras Plantas Med 14:712-716

Santos LB, Souza JK, Papassoni B, Borges DGL, Damasceno-Junior GA, Souza JME, Carollo CA, Borges FA (2013) Efficacy of extracts from plants of the Brazilian Pantanal against Rhipicephalus (Boophilus) microplus. Rev Bras Parasitol Vet 22:532-538

Sousa LAD, De Soares SF, Pires Júnior HB, Ferri PH, Borges LMF (2008) Avaliação da eficácia de extratos oleosos de frutos verdes e maduros de cinamomo (Melia azedarach) sobre Rhipicephalus (Boophilus) microplus (Acari: Ixodidae). Rev Bras Parasitol Vet 17:36-40

Szabó MPJ, Mukai LS, Rosa PCS, Bechara GH (1995) Differences in the acquired resistance of dogs, hamsters, and guinea pigs to repeated infestations with adult ticks Rhipicephalus sanguineus (Acari: Ixodidae). Braz J Vet Res Anim Sci 2:43-50

Szabó MPJ, Cunha TM, Pinter A, Vincentini F (2001) Ticks (Acari: Ixodidae) associated with domestic dogs in Franca region, São Paulo Brazil. Exp App Acarol 25:909-916

Szabó MPJ, Souza LGA, Olegário MMM, Ferreira FA, Pajuaba Neto AA (2010) Ticks (Acari: Ixodidae) on dogs from Uberlândia, Minas Gerais Brazil. Transbound Emerg Dis 57:72-74. doi:10.1111/j.18651682.2010.01111.x

Terassani E, dos Santos HJ, da Silva ID, Cardoso BK, de Souza SGH, Gazim ZC (2012) Efeito do extrato de Azadirachta indica em carrapatos Rhipicephalus (Boophilusmicroplus). Arq Cien Vet Zool Unipar $15: 197-200$

Viegas Junior C (2003) Terpenos com atividade inseticida: uma alternativa para o químico de insetos. Quim Nova 26:390-400

Walker JB, Keirans JE, Horak IG (2000) The Genus Rhipicephalus (Acari, Ixodidae). A guide to the brown ticks of the world. Cambridge University, Cambridge 